\title{
Analysis of Language and Scientific Literacy Skills for 4th Grade Elementary School Students through Discovery Learning and ICT Media
}

\author{
Endang Widi Winarni \\ University of Bengkulu, Indonesia, endangwidi@unib.ac.id

\section{Daimun Hambali} \\ University of Bengkulu, Indonesia, daimunhambali@gmail.com

\section{Endina Putri Purwandari} \\ University of Bengkulu, Indonesia, endinaputri@unib.ac.id
} conservation topics on students' language and scientific literacy. The matching only pretest and posttest control group design was used in this research. The participants were fourth-grade students in the academic year 2017-2018 with a total of 36 students. The research instrument for language literacy is essay questions, and scientific literacy is multiple-choice questions. Data were analyzed using the T-test. The analysis results show that there are differences in language and scientific literacy skills in students who were taught using discovery learning with ICT media and students who were taught using a conventional approach with visual media. The findings exhibited that: (1) there is an influence of the use of discovery learning with ICT media on students' language and scientific literacy, and (2) there is an influence of the interaction of discovery model with ICT language and scientific literacy in fourth-grade students. It is recommended for elementary school teachers and further researchers that the discovery learning model be adopted with ICT media, because: (1) scientific literacy can be developed through the understanding ability or part of language literacy, and (2) ICT media as the bamboo identification application as learning media can attract students' attention by creating an active and pleasant learning atmosphere.

Keywords: discovery learning, bamboo conservation, ICT media, language literacy, scientific literacy

\section{INTRODUCTION}

Literacy ability is one of the main aspects of education to strengthen $21^{\text {st }}$-century skills in learning competency. Therefore, students should be facilitated by learning that

Citation: Winarni, E. W., Hambali, D., \& Purwandari, E. P. (2020). Analysis of Language and Scientific Literacy Skills for 4th Grade Elementary School Students through Discovery Learning and ICT Media. International Journal of Instruction, 13(2), 213-222. https://doi.org/10.29333/iji.2020.13215a 
implements their knowledge into real life. Learning is not only oriented to mastering knowledge but also oriented to the learning process. According to Akbar (2017), literacy skills will be a provision for students to face real life in the globalization.

Literacy skills needed by students include language and scientific skills. Language literacy can stimulate students' thinking because it does not only enhance the language skills but also increases the overall knowledge. The subjects applied in thematic learning in elementary schools are Indonesian and Natural Sciences, as stated in National Education System Law No. 21 and 22 in 2016. Language learning, especially in elementary schools is inseparable from four language skills, namely listening, speaking, reading, and writing (Susanto, 2013). This is in accordance with the principles in the 2013 curriculum, namely developing language skills or literacy (National Education System Law, 2016).

Science contains four things, namely product, process, attitude, and technology (Cain, 1990). As a product, science is a collection of knowledge and a set of concepts and charts. As a process, science is a process used to study the object of study, find and develop scientific products. As an application, the theories of science will produce technology and provide convenience in life. The scientific learning process is more emphasized to skills, so students can find facts, build concepts, theories, and scientific attitudes. Through scientific learning, students can develop process skills and attitudes such as curiosity, honesty, perseverance, willingness to work together, responsibility, discipline, caring, and others.

Based on the Program for International Student Assessment or PISA, the scientific literacy skills of Indonesian students are still low compared with the international average scores. As quoted by the Organization for Economic Co-operation and Development (OECD), Indonesia's ranking in PISA in 2009 was 57 out of 67 countries with a score of 383. In 2012, Indonesia was ranked 64 out of 65 countries with a score of 382. Furthermore, in 2015, Indonesia was ranked 64 out of 72 participating countries, with a score of 403. Based on the three surveys, the Indonesian students' scores on scientific literacy skills were still far below the international standard scores set by the institution (OECD, 2015). The low learning outcomes of science relate to the scientific learning process that has not provided opportunities for students to develop critical thinking ability (Martaida, 2017).

If the intellectual abilities to understand the scientific concepts are developed, the children's language skills, both oral and written languages will develop. Basically, when children develop language skills such as reading skills, then indirectly require children able to develop high-level thinking skills. Furthermore, they are able to understand the meaning of what they read and apply to solve the problems of daily life.

Language literacy can stimulate students' thinking because it does not only enhance their language skills but also improves overall knowledge (Abidin, 2017). Scientific literacy is an effort to shape students to become active and participatory citizens in the real world context, and able to solve every problem. In scientific literacy, students can understand the environment, health, economics, and other problems faced by a modern 
society that are very dependent on technology and scientific development. Scientific literacy is more directed at how science can become the solution to make decisions on every problem. PISA modifies the definition of scientific literacy and formulates it in three dimensions, namely scientific concepts, scientific processes, and scientific situations (OECD, 2015).

Therefore, a teacher is required to develop students' abilities in language and scientific literacy with various approaches and learning media that can stimulate and motivate students to learn. When the teacher has been able to do this, the nation generation with global insight will be able to compete in the globalization era. However, not all teachers can create effective learning for students and are able to develop students' language and scientific literacy. The success of learning processes and outcomes is also influenced by media. The main functions of learning media are (1) as a tool to realize an effective learning process; (2) an integral part of the learning process; (3) integrated with the objectives and subject matter; (4) not merely entertainment tools or merely complementary; (5) accelerate the learning process and help students understand learning; and (6) improve the quality of learning.

Some educational researchers have developed various learning models to solve the problem in language and scientific literacy. Akgul (2004) examined the scientific literacy level for elementary school teachers in relation to thinking and inquiry. Some teachers had a contemporary understanding of scientific literacy. Scientific literacy is an effort to form students to become active and participatory citizens in the real world context and can solve any problems (Abidin, 2017). The most important part of building scientific literacy is how scientific facts can form certain skills in learning activities. Purwani (2018) analyzed the science competency on biodiversity topics for senior high school. This research showed that student's scientific literacy was low because students were not familiar with the socio-scientific issue. On the other hand, On the other hand, Djamahar (2018) designed the instructional kits to the empowerment of scientific literacy and metacognitive that using Cooperative Integrated Reading and Composition (CIRSA) approach. Udompong (2014) developed the diagnostic test to view students' defects clearly on the scientific literacy for elementary school students in Thailand. This test can improve the students' conceptions and help the teacher to reform the teaching and learning process. Furthermore, De Oliveira (2018) proposes a socio-historical and cultural subject to improve childhood and scientific literacy. This subject as a new concept of learning can be considered to make children more critical and active to experience different social and cultural contexts.

Based on the description above, the purpose of the study was to find out: (1) the influence of the discovery learning model with ICT media on language and scientific literacy; and (2) the influence of interaction models and instructional media on language and scientific literacy.

\section{METHOD}

The research design followed The Matching Only Pretest and Posttest Control Group Design by matching the subjects in the control group and the experimental group with 
homogeneity tests (Winarni, 2018a). Each class was given the pretest at the beginning of learning and the posttest at the end of learning. Pretest and posttest were conducted to determine the effectiveness of the variables studied.

\section{Participants}

The research population was fourth-grade students at SDN Bengkulu Tengah in Bengkulu Province, Indonesia in the academic year 2017-2018 consisting of 36 students (18 students from the experimental group and 18 students from the control group). The samples of research were IVA and IVB. Class IVA was randomly selected as the control group with 18 students and class IVB as the experimental group with 18 students. The learning theme in the two groups was the same, namely Theme 3 "Care for the living things", sub-theme 3 "Let's love the environment". The experimental class used ICT media with mobile learning while in the control class used visual and traditional media with paper-based learning.

\section{Data Collection}

\section{Instruments}

The instruments of research are essay questions for language literacy and multiplechoice questions for scientific literacy. There are five indicators for language literacy assessment, namely: (1) ability to take information, (2) ability to understand, (3) ability to develop interpretations, (4) ability to reflect and evaluate the text topic, and (5) ability to reflect and evaluate the text content. There are four indicators for scientific literacy, namely: (1) the scientific context, (2) the scientific competence, (3) the scientific knowledge, and (4) the attitude.

Scientific literacy assessments are carried out using a specific context, namely Bengkulu bamboo conservation. Bamboo conservation education aims to raise awareness and improve concern about Bengkulu bamboo potentials and encourage its protection. The scientific literacy measurement is not only based on issues in the curriculum but also on issues in children's personal life, local, and national. Bamboo conservation education is integrated into thematic learning in elementary school. The integration of conservation education aims to create future generations with positive behaviors towards natural resources. The bamboo identification application program is an Android mobile application known as "SIPA BAMBU". This application can be accessed freely at Google Play Store with the address https://play.google.com/store/apps/details?id=com.itunib.eldo_pc.sip abambu \& hl =en.

\section{Data Analysis}

The pretest and posttest scores from students were inputted into IBM SPSS Statistics Version 22 Software. The descriptive analysis technique was implemented to determine the student's score. Then, the normality and homogeneity test was held to know the normality of data. The independent t-test technique was implemented to find the significance of improvements between the two different training programs. Then, the nonparametric Mann Whitney test was held to test the distribution and the homogeneity of data. 
The validated instruments were examined on main field testing of the experimental and control groups to determine the mean, maximum, minimum, and $\mathrm{N}$-gain value. The $\mathrm{N}$ gain value indicates the increase of scientific and language literacy skills for each student. Then, the normality test using one-sample Kolmogorov-Smirnov $(\alpha=0.05)$ and the homogeneity test using the Levene test $(\alpha=0.05)$ were performed after N-gain data was obtained.

\section{FINDINGS}

\section{Results of Research}

Table 1

The Descriptive Score for Pretest and Posttest in Language and Scientific Literacy

\begin{tabular}{llllllll}
\hline & $\mathrm{N}$ & Min & Max & Sum & Mean & Std. Deviation & Variance \\
\hline Pre_Lang_Exp & 18 & 28.00 & 64.00 & 798.0 & 44.333 & 9.61004 & 92.353 \\
Pre_Lang_Con & 18 & 28.00 & 64.00 & 810.0 & 45.000 & 11.13024 & 123.882 \\
Pre_Sci_Exp & 18 & 50.00 & 90.00 & 1320.0 & 73.333 & 12.36694 & 152.941 \\
Pre_Sci_Con & 18 & 50.00 & 90.00 & 1280.0 & 71.111 & 12.78275 & 163.399 \\
Post_Lang_Exp & 18 & 46.00 & 76.00 & 1056.0 & 58.666 & 8.45751 & 71.529 \\
Post_Lang_Con & 18 & 34.00 & 64.00 & 846.0 & 47.000 & 7.76872 & 60.353 \\
Post_Sci_Exp & 18 & 60.00 & 100.00 & 1530.0 & 85.000 & 11.50447 & 132.353 \\
Post_Sci_Con & 18 & 60.00 & 100.00 & 1400.0 & 77.777 & 11.65966 & 135.948 \\
Valid N (listwise) & 18 & & & & & &
\end{tabular}

The results of language literacy tests show that the mean scores of pretest and posttest in the control class were lower than in the experimental class. The scientific literacy had higher scores for pretest and posttest than those of the language literacy. The results of normality test between pretest and posttest for the experimental and control group shown in Table 2.

Table 2

The Normality Test for Experimental and Control Groups

\begin{tabular}{lllllll}
\hline & \multicolumn{3}{l}{ Kolmogorov-Smirnov $^{\mathrm{a}}$} & \multicolumn{3}{l}{ Shapiro-Wilk } \\
\cline { 2 - 7 } Variable & Statistic & df & Sig. & Statistic & Df & Sig. \\
\hline Pre_Lang_Exp & .137 & 18 & $.200^{*}$ & .956 & 18 & .519 \\
Pre_Lang_Con & .173 & 18 & .160 & .942 & 18 & .309 \\
Post_Lang_Exp & .198 & 18 & .060 & .931 & 18 & .199 \\
Post_Lang_Con & .205 & 18 & .044 & .916 & 18 & .109 \\
Pre_Sci_Exp & .162 & 18 & $.200^{*}$ & .914 & 18 & .100 \\
Pre_Sci_Con & .146 & 18 & $.200^{*}$ & .924 & 18 & .155 \\
Post_Sci_Exp & .168 & 18 & .193 & .912 & 18 & .092 \\
Post_Sci_Con & .187 & 18 & .097 & .924 & 18 & .154 \\
\hline
\end{tabular}

Based on Table 2, the pretest and posttest data were normally distributed for all class and literacy treatment. All of the pretest and posttest score had Sig > 0.05. Moreover, the pretest and posttest data were homogenous (in Table 3), which scientific and language literacy score had $\mathrm{Sig}>0.05$. 
Table 3

The Homogeneity Test for the Experimental and Control group

\begin{tabular}{lllll}
\hline & Levene Statistic & df1 & df2 & Sig. \\
\hline Exp_Lang & .139 & 2 & 15 & .871 \\
Exp_Sci & 1.593 & 2 & 15 & .236 \\
Con_Lang & .857 & 2 & 15 & .444 \\
Con_Sci & .291 & 2 & 15 & .752 \\
\hline
\end{tabular}

Based on table 4 below, the experimental and control groups for the scientific literacy group were significantly different after implemented the ICT media learning in the experimental class. The t-test in pretest shows $\mathrm{Sig}=0.855$ for language literacy and Sig $=0.508$ for scientific literacy. This indicates that the literacy skills of students were not significantly different for pretest in the experiment and control group ( $\mathrm{Sig}>0.05)$. The t-test in posttest shows Sig $=0.000$ for language literacy and Sig $=0.033$ for scientific literacy. This indicates that the skills of students were significantly different (Sig < $0.05)$.

Table 4

T-Test for the Experimental and Control Group

\begin{tabular}{|c|c|c|c|c|c|c|c|c|c|}
\hline & & \multicolumn{5}{|c|}{ Paired Differences } & \multirow[b]{3}{*}{$\mathrm{t}$} & \multirow[b]{3}{*}{ df } & \multirow{3}{*}{$\begin{array}{l}\text { Sig. }(2- \\
\text { tailed) }\end{array}$} \\
\hline & & \multirow[b]{2}{*}{ Mean } & \multirow{2}{*}{$\begin{array}{l}\text { Std. } \\
\text { Deviation }\end{array}$} & \multirow{2}{*}{$\begin{array}{l}\text { Std. } \\
\text { Error } \\
\text { Mean }\end{array}$} & \multicolumn{2}{|c|}{$\begin{array}{l}95 \% \text { Confidence } \\
\text { Interval of the } \\
\text { Difference }\end{array}$} & & & \\
\hline & & & & & Lower & Upper & & & \\
\hline Pair 1 & $\begin{array}{l}\text { Pre_Lang_Exp - } \\
\text { Pre_Lang_Con }\end{array}$ & -.6667 & 15.2469 & 3.5937 & -8.2488 & 6.9154 & -.186 & 17 & .855 \\
\hline Pair 2 & $\begin{array}{l}\text { Pre_Sci_Exp - } \\
\text { Pre_Sci_Con }\end{array}$ & 2.2222 & 13.9560 & 3.2894 & -4.7179 & 9.1624 & .676 & 17 & .508 \\
\hline Pair 3 & $\begin{array}{l}\text { Post_Lang_Exp - } \\
\text { Post_Lang_Con }\end{array}$ & 11.6667 & 7.2679 & 1.7130 & 8.0523 & 15.2809 & 6.810 & 17 & .000 \\
\hline Pair 4 & $\begin{array}{l}\text { Post_Sci_Exp - } \\
\text { Post_Sci_Con }\end{array}$ & 7.2222 & 13.1978 & 3.1107 & .6590 & 13.7853 & 2.322 & 17 & .033 \\
\hline
\end{tabular}

Based on data, there are: (1) a significant difference in language literacy skills between students with discovery learning and students with conventional learning; and (2) a significant difference in scientific literacy between student interaction in discovery learning with ICT media and in conventional learning with visual media.

\section{DISCUSSION}

The complexity of students' competency in the $21^{\text {st }}$ century changes the paradigm from the teaching paradigm to the learning paradigm. This means that teacher-centered learning should be changed to learner-centered one. In this case, the teacher is no longer the only source of learning but rather serves as a facilitator in the learning process. The vision of 21 st century education is more based on the learning paradigm with the following orientation: (1) learning to think oriented to logical and rational knowledge, (2) learning to do oriented to solving problems, (3) learning to be independent that oriented to character formation, and (4) learning to live together oriented to being tolerant and ready to work together. 
Primary students need learning that can stimulate their curiosity, need a variety of learning media that can stimulate their thinking and dare to communicate what is on their mind and can develop language skills. The implementation of thematic learning using Discovery Learning models with ICT media can improve language and scientific literacy for elementary students. The findings of this study, in accordance with Asyhari's statement (2015) and Winarni's (2018a) that in the learning model implementation, the teacher acts as a facilitator while students find and experience themselves. Discovery learning can increase the intellectual potential, generate intrinsic and extrinsic motivation, help students to find, and help to strengthen students' memories.

The research results that learning using the discovery model can improve language and scientific literacy significantly are in line with the research results by Winarni et al. (2018b). The improvement was achieved through (1) stimulate, stimulation can arouse curiosity, (2) identify, identification of problems can help students to determine the most relevant problems and formulate hypotheses, (3) data collection, students get the widest opportunity in collecting relevant information, (4) data processing, students receive guidance from teacher to answer problems based on the results of data processing, (5) verification, students with teacher guidance can prove the hypothesis based on the results of data processing, and (6) draw conclusions, students are able to draw conclusions based on the results evidence. With a series of steps, students: (1) have the opportunity to learn discovery actively, especially in a concrete context; (2) have learned strategy to form a question and answer also work together effectively; and (3) have found more meaningful concepts and principles.

The increase in scientific literacy students using discovery learning and ICT media has achieved the goals of science education in elementary schools, namely: (1) awareness of the beauty of nature to increase trust to God; (2) knowledge about the basis of principles and concepts, nature facts, interdependent relationships, and relationship between science and technology; (3) skills and abilities to handle equipment, solve problems, and make observations; (4) scientific attitudes, including skeptics, critical, sensitive, objective, honest, open, true, and work together; (5) habits to develop the ability of inductive and deductive analytical thinking by using scientific concepts and principles to explain various natural events; (6) appreciation of science to enjoy and realize the beauty of nature and its application in technology.

The research results on scientific and language literacy for elementary school students is very important because these abilities greatly determine their success in mastering other subjects. Nurdiyanti and Suryanto (2010) said that children's language skills, especially reading and writing, greatly determine their success in mastering various other subjects. Whereas in groups that carry out learning with visual media, information obtained by the students is very limited.

In elementary school, natural science is one of the subjects that occupy an important role in education. Science can be a provision for students to face challenges in the global era. Science education as part of education is generally responsible and plays an important role in forming students to think critically, logically, creatively, innovatively, and local 
competitiveness. Science education is expected to be the main foundation of education for students by knowing science more contextually and implementing in daily life.

Therefore, we need a learning model that can prepare students to have good competence and scientific literacy skills. Scientific literacy can be interpreted as the ability to understand science, communicate science (both oral and written), and apply science to solve problems, so decisions can be made based on scientific considerations. Literacy is not only focused on the reading and writing process but also other activities such as observing, asking, trying, reasoning, and communicating (Djamahar, 2018).

The use of ICT media can significantly improve the scientific and language literacy of elementary school students. This finding, in line with Winarni's research (2018b) that ICT media can facilitate students to make observations, classifications, predictions, and determinations to become more contextual. Learning media is an intermediary that can be used to convey an idea from the conveyor to the recipient of the message. In this case, the conveyor is the teacher, and the recipient of messages is the student, the media is used so to make the learning process more effective. Learning with multimedia can motivate students' thoughts, feelings, attention, and abilities. The learning process with multimedia will further build the competencies of a student called scientific literacy. This is in line with the research conducted by Oktarisa (2016) that learning with multimedia can improve the mastery of concepts and the competencies of science compared with learning models without multimedia.

According to Winarni (2018c), ICT and multimedia can be effective in learning because they can: (1) train media and information skills on needs of the $21^{\text {st }}$ century; (2) create an active and pleasant classroom atmosphere; (3) convey meaningful learning; (4) give students access to explore and high creativity; (5) train communication skills, collaborating, working in groups; and (7) bring students to a higher level of thought. The results of Winarni's study, et al. (2018b) show that ICT media in learning can create an active and enjoyable learning atmosphere for fourth-grade students in elementary school. Students are facilitated by gathering information, using multimedia provided by teachers such as videos, images, and reading material about bamboo conservation in Bengkulu. Students can gather information through various activities involving the five senses to form a broader understanding. When activities to prove and process information, students can specify the information they have obtained. At the end of activity, students can present information that has been obtained in the learning process that has taken place.

Through the discovery learning and ICT media, students have a goodwill to be involved in discourse reasoning about science and technology. The use of media in learning can also attract students' attention and improve student motivation in learning. The main function of learning media is to visualize something that cannot be seen or difficult to see so that it appears clearly and can give understanding or improve the perceptions.

The bamboo identification application is designed to identify the bamboo species easily (Purwandari, 2017). This application has proven effective to use and accurate for identifying bamboo. Futhermore, Purwandari (2017) stated that the bamboo 
identification application shown high accuracy and more reliable identification results compared to manual identification. The dissemination of science and technology was an instrument that emerged from the context of globalization and needed to solve the problems of the $21^{\text {st }}$ century.

The impact of learning activities using discovery learning and ICT media about bamboo conservation is developed to (1) explain scientific phenomena, (2) evaluate explanations for various natural phenomena and technology; (3) evaluate and design scientific research, (4) describe and evaluate scientific investigations, (5) propose ways to handle scientific questions; (6) interpret scientific data and evidence, (7) analyze and evaluate data, claims, and arguments in various representations, and (8) draw scientific conclusions. Based on the explanation above, it can be said that to improve students' language and scientific literacy skills, it is recommended to use the discovery of learning with ICT media. These skills can be used by students to develop, analyze, interpret, and communicate the ideas to be a scientifically literate person.

\section{CONCLUSION}

In this paper, we conclude that the discovery of learning with ICT media for scientific and language literacy can improve the student's skills rather than conventional learning. There is a significant influence of the use of discovery learning with ICT media on language and scientific literacy in fourth-grade elementary school students. Scientific and language literacy empowerment should be conducted to make students more independent in the learning process.

It is recommended for elementary school teachers and future researchers that the discovery learning model be adopted with ICT media, because scientific literacy can be developed through reading comprehension skills or one part of language literacy and ICT media with identification bamboo species application as learning media can attract students' attention by creating an active and pleasant atmosphere.

\section{ACKNOWLEDGEMENT}

We would like to thank the Directorate of Higher Education, Ministry of Research, Technology, and Higher Education, Republic Indonesia, for financial support throughout the research grant program.

\section{REFERENCES}

Abidin, Y., Mulyati, T., dan Yuansyah, H. (2017). Pembelajaran literasi: Strategi Meningkatkan Kemampuan Literasi Sains, Membaca, dan Menulis. Jakarta: Bumi Aksara.

Akbar, A. (2017). Membudayakan Literasi Dengan Program 6m Di Sekolah Dasar. Jurnal PGSD STKIP sebelas April Sumedang. JPSD, 3(1).

Asyhari, A. (2015). Profil Peningkatan Kemampuan Literasi Sains Siswa Melalui Pembelajaran Saintifik. Jurnal Ilmiah Pendidikan Fisika, 4(2). https://doi.org/10.24042/jpifalbiruni.v4i2.91.

Cain, S. E., \& Evans, J. M. (1990). Sciencing: An involvement approach to elementary science methods. Prentice Hall. 
De Oliveira, A.S., Simon, V. L. B., \& Simon, A. (2018) Childhood and scientific literacy: Contributions of history and epistemology. Open Journal of Social Sciences, 6, 216-225. https://doi.org/10.4236/jss.2018.68017.

Djamahar, R., Ristanto, R. H., Sartono, N., \& Ichsan, I. Z. (2018). CIRSA: Designing instructional kits to empower $21^{\text {st }}$ century skill. Educational Process: International Journal, 7(3), 200-208. http://dx.doi.org/10.22521/edupij.2018.73.4.

Macaroglu Akgul, E. (2004). Teaching scientific literacy through a science technology and society course: Prospective Elementary science teacher case. TOJET, 3(4), 8.

Martaida, T., Bukit, N., \& Ginting, E. M. (2017). The effect of discovery learning model on student's critical thinking and cognitive ability in junior high school. IOSRJRME, 7(6), 1-8.

National Education System Law. 2016. Indonesia Education Law No. 21 and No.22 about the National Education System in Indonesia. Indonesia Government.

Nurdiyanti, E., \& Suryanto, E. (2010). Pembelajaran Literasi Mata Pelajaran Bahasa Indonesia Pada Siswa Kelas V Sekolah Dasar. Jurnal. Jilid, 13(2).

Oktarisa, Y. (2016). Penerapan Model Pembelajaran Berbasis Pengalaman Berbantuan Multimedia Untuk Meningkatkan Penguasaan Konsep Dan Kompetensi Sains Siswa. Jurnal Untirta.

OECD. (2015). Program for international student assessment (PISA) for Indonesia. Paris: OECD.

Purwandari, E. P., Yani, A. P., Sugraha, R., Anggriani, K., \& Winarni, E. W. (2017). Online expert systems for bamboo identification using case-based reasoning. IJECE, 7(5), 2766-2772.

Purwani, L D. F., Sudargo F., \& Surakusumah W. (2018). Analysis of student's scientific literacy skills through socio-scientific issue's test on biodiversity topics. Journal of Physics: Conf. Ser., 1013, 012019. doi:10.1088/1742-6596/1013/1/012019.

Susanto. (2013). Teori Belajar dan Pembelajaran di Sekolah Dasar. Jakarta: Kencana Prenadamedia Group.

Udompong, L., Wongwanich, S. (2014). Diagnosis of the scientific literacy characteristics of primary students. $5^{\text {th }}$ World Conference on Educational Sciences WCES 2013. Elsevier Publisher. doi:10.1016/j.sbspro.2014.01.1079.

Winarni, E. W. (2018). Teori dan Praktik Penelitian Kuantitatif Kualitatif. Jakarta: Bumi Aksara.

Winarni, E. W., Purwandari, E. P., \& Hervianti, Y. (2018b). Mobile educational game for earthquake disaster preparedness in elementary school. ARPN Journal of Engineering and Applied Sciences, 13(7), 2612-2618.

Winarni, E. W., Purwandari, E. P., Lusa, H., \& Dadi, S. (2018). The impact of thematic learning integrated ICT in Tabot bengkulu as cultural ceremony toward social interaction knowledge in elementary School. Asian J. of Edu. and Training, 4(2), 70-74. 